\title{
Effect of ad libitum intake of an electrolyte repository in horses that underwent a polo game
}

\section{Efeito da ingestão ad libitum de repositor hidroeletrolítico em equinos submetidos a jogo de polo}

\author{
Lorena Chaves Monteiro ${ }^{1}$; José Dantas Ribeiro Filho ${ }^{2 *}$; \\ Waleska de Melo Ferreira Dantas; ; Bruna Maria Ribeiro'; \\ Micheline Ozana da Silva ${ }^{1}$; Caio Monteiro Costa ${ }^{1}$; Pedro Ancelmo Nunes Ermita \\ Gláucia Matos Marques da Silva ${ }^{1}$; Carlos Henrique Coelho de Campos ${ }^{4}$
}

\begin{abstract}
The objective of this study was to assess the effects of an electrolyte and energy repository on the hematologic and biochemical variables of horses after a polo game and compare them to the effects of a commercial electrolyte repository and water. Twelve healthy horses, aged 5 to 10 years, mean body weight $356.25 \pm 25.6 \mathrm{~kg}$ and in training for polo games, were randomly divided into three groups of four animals each and received one of three treatments. Animals participated in a 7-minute polo game. At the end of the match, they were taken to individual stalls where they received treatments for spontaneous hydration for 6 hours. Treatments were Hydroelectrolytic and Energy Repository (RHE) containing sodium, chloride, potassium, calcium, magnesium, dextrose, maltodextrin and, sucrose; and Commercial Paste (PCO) containing calcium, fructooligosaccharides, glycine, magnesium, potassium, sodium, and ad libitum water. The control group (Water) received water. Blood samples were collected as follows: just before the beginning of exercise (T0), immediately after exercise (T1), 3 hours after the end of exercise (T3), and 6 hours after the end of exercise (T6). The volume of voluntary intake was measured at T3 and T6. Packed cell volume and serum concentrations of sodium, potassium, chloride, calcium, magnesium, phosphorus, creatinine, total protein, plasma glucose, and lactate were measured. Data were submitted to descriptive statistics (mean \pm standard deviation), Lilliefors and Cochran \& Bartlett tests, analysis of variance (ANOVA), and Tukey or Duncan tests at a 5\% significance level. The net volume ingested by the RHE group was higher than the PCO and control groups. In all groups, a reduction in chloride concentration and increases in packed cell volume, protein, creatinine, glucose, and lactate concentrations were observed in $\mathrm{T} 1$. These variables returned to the values found at $\mathrm{T} 0$ throughout the rehydration phase (T3 and T6). It is concluded that the ingestion of the hydroelectrolytic energy repository does not cause alteration in the biochemical profile of the animals.
\end{abstract}

Key words: Equines. Exercise. Sports Drink. Rehydration.

\section{Resumo}

O presente estudo objetivou avaliar os efeitos de um repositor hidroeletrolítico e energético oferecido a equinos que participaram de jogo de polo sobre as variáveis hematológicas e bioquímicas desses animais,

\footnotetext{
${ }^{1}$ Discentes, Universidade Federal de Viçosa, UFV, Viçosa, MG, Brasil. E-mail:lorena.monteiro@ufv.br; bruna.ribeiro.vet@gmail. com; michelineozana@gmail.com; caiomonteiro@me.com; pedro.ermita2@gmail.com; ninha.an@hotmail.com

2 Prof., UFV, Viçosa, MG, Brasil. E-mail: dantas@ufv.br

3 Prof., União de Ensino Superior de Viçosa, UNIVIÇOSA, Viçosa, MG, Brasil. E-mail:waleskaferreiradantas@gmail.com

${ }^{4}$ Oficial Veterinário, Exército Brasileiro, Ministério da Defesa, Belo Horizonte, MG, Brasil. E-mail: henriqueibex@gmail.com

* Author for correspondence
} 
além de compará-los aos efeitos de um repositor eletrolítico comercial e água. Doze equinos hígidos, com idade entre 5 e 10 anos, peso corporal médio 356,25 $\pm 25,6 \mathrm{~kg}$ e em treinamento para jogos de polo foram aleatoriamente divididos em três grupos, com quatro animais cada, e submetidos a um dos três tratamentos. Os animais foram submetidos a sete minutos do jogo de polo. Ao término, foram levados às baias individuais onde receberam os respectivos tratamentos para hidratação espontânea durante seis horas. Os tratamentos foram: grupo Repositor Hidroeletrolítico e Energético (RHE) composto por sódio, cloreto, potássio, cálcio, magnésio, dextrose, maltodextrina e sacarose; grupo Pasta Comercial (PCO) contendo cálcio, fruto-oligossacarídeos, glicina, magnésio, potássio e sódio, e água ad libitum; grupo controle (Água). As amostras de sangue foram coletadas nos seguintes tempos: imediatamente antes do início do exercício (T0); imediatamente após o exercício (T1); três horas após o término do exercício (T3); e seis horas após o término do exercício (T6). O volume de ingestão voluntário foi mensurado nos tempos T3 e T6. O volume globular e as concentrações séricas de sódio, potássio, cloreto, cálcio, magnésio, fósforo, creatinina, proteína total e plasmáticas de glicose e lactato foram mensuradas. Os dados foram submetidos a estatística descritiva (médias \pm desvio-padrão), aos testes de Lilliefors e Cochran \& Bartlet, à análise de variância (ANOVA), e aos testes de Tukey ou Duncan a um nível de significância de 5\%. O volume líquido ingerido pelo grupo RHE foi superior aos grupos PCO e Água. Em todos os grupos observou-se no T1 redução da concentração de cloreto e aumento nos valores de volume globular, proteína, creatinina, glicose e lactato. Essas variáveis retornaram aos valores encontrados em T0 ao longo da fase de reidratação (T3 e T6). Conclui-se que o repositor hidroeletrolítico energético testado foi bem aceito pelos equinos e que a sua ingestão não ocasionou alteração no perfil bioquímico dos animais.

Palavras-chave: Cavalos. Exercício. Bebida Esportiva. Reidratação.

\section{Introduction}

Physical exercise interferes with the balance of various substances such as glycogen, fat, and electrolytes, promoting an increase in blood circulation, increasing energy, and activating thermoregulatory mechanisms to maintain body temperature (COENEN, 2005). During practice, reversible changes in homeostasis occur, which can be detected by laboratory tests (GONDIN et al., 2013) and clinical examinations. These variations are influenced by the physical conditioning of the animal (SICILIANO et al., 1995) and by the intensity of the modality of practice (ASSENZA et al., 2014).

To perform physical activity, it is necessary to transform chemical energy into mechanical energy. This process is inefficient, and approximately $80 \%$ of the energy is lost as heat. The primary thermoregulatory mechanism used by equines is loss of heat through evaporation of sweat (HODGSON et al., 1994). Sweating allows the dissipation of up to two thirds of the metabolic heat generated, with sweat production reaching up to $10 \mathrm{~L} \mathrm{~h}^{-1}$. Equine sweat is hypertonic compared to plasma, containing approximately $130 \mathrm{mmol} \mathrm{L}^{-1}$ sodium, $150 \mathrm{mmol} \mathrm{L}^{-1}$ chloride, and $45 \mathrm{mmol} \mathrm{L}^{-1}$ potassium (MCCUTCHEON et al., 1999). Usually, the diet's electrolyte replacement capacity is lower than the electrolytes lost due to sweating during sports (LINDINGER; ECKER, 2013). Studies of horses submitted to resistance testing report a significant reduction in the body weight of these animals associated with the loss of fluids due to sweat (TEIXEIRA-NETO et al., 2004; PUOLI FILHO et al., 2007). Thermoregulatory mechanisms generate a water deficit and electrolyte and acid base imbalances. Thus, there is a decrease in the animal's athletic performance and an increase in the recovery period after physical activity (FLAMINIO; RUSH, 1998; CROCOMO et al., 2009).

Fluid and electrolyte replacement after intense exercise and the animal's conditioning are key points for optimal performance (GOMES, 2014). The ingestion of water alone after body fluid loss is not effective in promoting hydration when compared to electrolyte replacement solutions containing carbohydrates (HYYPPÄ et al., 1996; MARLIN et al., 1998). Water and electrolyte 
replacement allows rapid restoration of hydration status and maintenance of plasma osmolarity, restores fluid and electrolytes lost through sweating, diminishes the development of muscle fatigue, and improves the rate of glycogenesis by the muscles, thus contributing to improved athletic performance (WALLER et al., 2007). The administration of electrolytic pastes to equine athletes is the most common practice when the goal is to restore the electrolytes lost during exercise. However, there is no evidence of the efficacy of these products alone on animal performance (SAMPIERI et al., 2006). Administration of electrolytic paste is an efficient strategy to increase water consumption; therefore, it helps with hydroelectrolytic replacement when compared to isolated water intake (DUSTERDIECK et al., 1999; SOSA LEÓN et al., 1998; TEIXEIRANETO et al., 2004). However, frequent administration of electrolytic paste to horses may exacerbate or even induce the development of gastric ulcers (HOLBROOK et al., 2005).

Ad libitum intake of hydroelectrolytic carbohydrate repositories favors the correction of water and electrolyte imbalances and acid-base disorders triggered by physical exercise as observed by Donner (2013). It is indisputable that the solutions used for hydroelectrolytic replacement contain the main electrolytes lost by sweating, such as sodium, potassium, chloride, calcium, magnesium, and a source of energy, which may be glucose, dextrose, or maltodextrin (LINDINGER; ECKER, 2013; RIBEIRO FILHO et al., 2014b).

Therefore, the present study aimed to evaluate the effects of hydroelectrolytic repositories offered to horses after a polo match on hematological and biochemical variables, and to compare them to the effects of water-only intake and a commercial electrolytic repository associated with water.

\section{Materials and Methods}

The present study was conducted at the Agulhas Negras Military Academy (AMAN) in the municipality of Resende, Rio de Janeiro, located at an altitude of approximately 407 meters, latitude $22^{\circ}$ $28^{\prime} 8^{\prime \prime} \mathrm{S}$ and longitude $44^{\circ} 26^{\prime} 49^{\prime \prime} \mathrm{W}$. The research project was approved by the Federal University of Viçosa's Ethics Committee on the Use of Animals, protocol number 05/2015.

Twelve healthy horses, aged 5 to 10 years old, body weight $356.25 \pm 25.6 \mathrm{~kg}$, with good body scores, were used. All were in training for polo matches, undergoing an intensive management program with feeding composed of chopped elephant grass (Pennisetum purpureum), Tifton hay (Cynodon sp.), 1\% body weight feed, and water and mineral supplements ad libitum.

The animals were randomly distributed into three groups; each group included four animals. Each group received one of three treatments. After a 24-hour interval, all groups were submitted to a repeat of the same experimental protocol. Following the animal training routine conducted by AMAN, polo matches took place between 08:00 and 11:00 a.m. All animals were ridden and heated for 10 minutes at a walk. Then, following the Brazilian Polo Confederation's guidelines, the animals were submitted to one period of a polo match ( 7 minutes of physical activity). The animals were then unsaddled, bathed, and exposed to the sun for 10 minutes. After that, they were taken to individual stalls where they were treated. The Hydroelectrolytic Repository (RHE) group received an electrolytic solution containing sodium chloride (Sulfal Laboratory), potassium chloride (Sulfal Laboratory), calcium gluconate (Sulfal Laboratory), magnesium pidolate (Pidomag $^{\circledR}$, Baldacci Laboratory), dextrose (Sulfal Laboratory), maltodextrin (Maximus Pure Maltodextrin $^{\circledR}$, ARVE Laboratory Indústria e Comércio Ltda.) and sucrose (Açúcar Alvinho ${ }^{\circledR}$, Companhia Agrícola Pontenovense Usina Jabotica) diluted in 1,000 $\mathrm{mL}$ of water (formula protected by patent process). The Commercial Paste (PCO) group received commercial paste (Electro Equi $\mathrm{Gel}^{\circledR}$, Organnact Laboratory, Curitiba, Brazil) containing $14.7 \mathrm{~g}$ calcium, $250 \mathrm{mg}$ fructooligosaccharides, 1.6 
g glycine, $0.824 \mathrm{~g}$ glucose, $420 \mathrm{mg}$ magnesium, $2.6 \mathrm{~g}$ potassium, and $8.23 \mathrm{~g}$ sodium + water ad libitum. The control (Water): group received water ad libitum. The hydroelectrolytic repositories and water were supplied ad libitum in graduated buckets. The electrolyte paste was orally administered to the animals according to the manufacturer's recommendations ( $5 \mathrm{~g}$ per $100 \mathrm{~kg}$ body weight) as soon as they reached their stalls.

Blood samples were taken by venipuncture of the external jugular vein with $21 \mathrm{G}$ needles and 4-mL laboratory sample tubes containing a glycolytic inhibitor and anticoagulant to obtain plasma (BD Vacutainer Fluoride/EDTA ${ }^{\circledR}$ Tube, Becton and Dickinson Indústria Cirúrgica Ltda., Londrina, Brazil), and 10-mL laboratory sample tubes with a clot activator to obtain serum (BD Vacutainer ${ }^{\circledR}$, Becton and Dickinson Indústria Cirúrgica Ltda.). Samples were collected immediately before the beginning of exercise (T0), immediately after exercise (T1), and 3 (T3) and 6 hours after the end of exercise (T6). After drawing blood, serum and plasma aliquots were stored at $-20^{\circ} \mathrm{C}$ until laboratory analysis. The ingested liquid volume was measured at $\mathrm{T} 3$ and $\mathrm{T} 6$.

The laboratory analyses were performed at the Laboratory of Clinical Pathology at the Federal University of Viçosa's Veterinary Department. The globular volume was measured using the manual microhematocyte technique. The biochemical evaluation was performed by measuring serum concentrations of sodium and potassium using flame photometry (Flame Spectrophotometer B462, Micronal, S.A., São Paulo, Brazil). Serum chloride concentrations (Chloride Liquiform ${ }^{\circledR}$ kit, Labtest Diagnóstica S.A., Lagoa Santa, Brazil), calcium (Calcium kit, In Vitro Diagnóstica Ltda., Itabira, Brazil), magnesium (Magnesium Mono kit, In Vitro Diagnóstica Ltda.), phosphorus (Phosphorus UV kit, In Vitro Diagnóstica Ltda.), creatinine (Creatinine kit, In Vitro Diagnóstica Ltda.), total protein (Total Protein kit, In Vitro Diagnóstica Ltda.), glucose plasma concentration (Glucose Liquicolor kit, In
Vitro Diagnóstica Ltda.), and lactate (Lactate kit, Labtest Diagnóstica S.A.) were measured using a clinical chemistry analyzer (Humastar $300^{\circledR}$, Human Gesellschaft für Biochemica und Diagnostica mbH, Wiesbaden, Germany).

The descriptive statistics (mean \pm standard deviation) of all the studied variables were conducted. The data were evaluated by the Lilliefors and the Cochran \& Bartlet tests to verify normality and variance homogeneity, respectively. The data were then submitted to an analysis of variance (ANOVA) based on the planning of repeated measures over time to verify the effects of the treatments at different observation times and the interaction between times and treatments. The contrasts between averages were performed using the Tukey or Duncan tests (the latter for data with a coefficient of variation $>15 \%$ ). Statistical analysis was performed using the statistical program SAEG 9.1 (2007); $\mathrm{P}<0.05$ was considered significant.

\section{Results and Discussion}

The mean volume ingested by the RHE animals at $\mathrm{T} 3$ and $\mathrm{T} 6$ was higher $(\mathrm{P}<0.05)$ than the volume ingested by the PCO and control groups (Table 1). The highest intake of RHE probably occurred due to its superior palatability compared to the other treatments. The palatability of a solution containing electrolytes is determined primarily by the presence of carbohydrates in its composition. In humans, when comparing the voluntary intake of hydroelectrolytic carbohydrate repositories with water intake, it is observed that the first option is ingested in a larger volume (SHIRREFFS et al., 2005). Therefore, it is believed that the highest volume of the RHE ingested by the animals in the present experimental trial was due to its better palatability, since it contained sucrose, dextrose, and maltodextrin in addition to electrolytes. Donner (2013) used a hydroelectrolytic repository similar to the one used in the present trial in equines after gait training; they registered similar consumption when compared to a control group that received water. 
Table 1. Mean and standard deviation of the ingested volume of the Hydroelectrolytic Repository (RHE), Commercial Paste and Water (PCO), and Control (Water) ingested by horses during the treatment phase 3 (T3) and 6 hours (T6) after the end of a polo game.

\begin{tabular}{lccc}
\hline \multirow{2}{*}{ Groups } & \multicolumn{2}{c}{ Time evaluation } & \multirow{2}{*}{ Total } \\
\cline { 2 - 3 } & \multicolumn{1}{c}{ T3 } & $4.5 \pm 5.2^{\mathrm{Ab}}$ & $22.7 \pm 9.2^{\mathrm{A}}$ \\
RHE & $18.2 \pm 10.4^{\mathrm{Aa}}$ & $1.93 \pm 1.9^{\mathrm{Ba}}$ & $7.4 \pm 3.4^{\mathrm{B}}$ \\
PCO & $5.5 \pm 3.4^{\mathrm{Ba}}$ & $2.0 \pm 2.5^{\mathrm{Ba}}$ & $8.1 \pm 4.2^{\mathrm{B}}$ \\
Water & $6.1 \pm 3.3^{\mathrm{Ba}}$ & $\mathrm{y}$ &
\end{tabular}

Mean values followed by different lower case letters on the same line or by upper case letters in the same column are different $(\mathrm{p}<0.05)$ according to the Tukey test.

There was no difference between the PCO and control groups (Table 1). It is common to use veterinary products in the form of pastes containing electrolytes and carbohydrates, which are usually supplied to animals before, during, or after physical activity. The recommendation of the manufacturing laboratories is to make water available to the animal after paste administration. According to the laboratories, this stratagem is based on the principle that after ingestion of the paste, the animal will drink a larger volume of water, which is desirable in the rehydration process. However, the results of the present study showed that in the group of animals that received the commercial paste, the average spontaneous water intake was $7.4 \mathrm{~L}$ per animal; however, in the control group, the average volume ingested per animal was $8.1 \mathrm{~L}$ (Table 1). This result contradicts the recommendations of the manufacturers of these products.

As expressed in Table 2, total serum protein (PTS) concentrations and packed cell volume values showed similar behavior. No difference $(\mathrm{P}>0.05)$ was detected between the treatments, only between the times $(\mathrm{P}<0.05)$. There was an increase at $\mathrm{T} 1$ and a decrease at T3 and T6 in all treatment groups. As cited by Zobba et al. (2011), polo matches cause a reduction in plasma volume resulting from loss of water due to sweating, determining the increase in PTS. However, during high intensity exercise, there is a translocation of fluid with a low concentration of proteins from the intravascular space into the interstitial and intracellular spaces (GONDIN et al., 2013). Thus, there is an increase in total serum protein concentration. In addition, physical activity promotes the secretion of catecholamines leading to splenic contraction and addition of erythrocytes to the bloodstream to meet the increased demand for tissue oxygen, especially muscle (HYYPPÄ, 2005), intensifying the increase in packed cell volume, confirming the raise in PTS and packed cell volume in the animals of the present T1 trial.

At T3 and T6, both variables in all groups returned to values similar to those observed at T0 (Table 2). This decrease was caused by the rehydration of the animals during that period and, possibly, by the end of the mechanisms mentioned by Gondin et al. (2013) and Hyyppä (2005).

The serum creatinine values described in Table 2 were not different between treatments $(\mathrm{P}>0.05)$. However, there was a difference during the experimental phase treatments $(\mathrm{P}<0.05)$. The increase in creatinine at $\mathrm{T} 1$ (end of physical activity) was detected in all treatment groups. This effect was caused by decreased renal perfusion during physical activity. According to Santos (2006), submaximal and maximal exercise causes increased creatinine in the blood due to hemoconcentration. In the rehydration period, there was a decrease in creatinine at $\mathrm{T} 3$ and $\mathrm{T} 6$ in the animals of all treatment groups, showing that the treatments had an effect (Table 2). In addition to the effect of hemodilution generated by rehydration, the expansion of blood volume generated by rehydration may have caused an increase in the production of urine, allowing creatinine excretion. 
Table 2. Mean and standard deviation of total protein concentration, packed cell volume, creatinine, glucose, and lactate concentrations in horses before exercise (T0), immediately after exercise (T1), and after 3 (T3) and 6 (T6) hours after exercise.

\begin{tabular}{|c|c|c|c|c|}
\hline \multirow{2}{*}{ Groups } & \multicolumn{4}{|c|}{ Time evaluation } \\
\hline & T0 & $\mathrm{T} 1$ & $\mathrm{~T} 3$ & T6 \\
\hline \multicolumn{5}{|c|}{ Protein $\left(\mathrm{g} \mathrm{dL}^{-1}\right)$} \\
\hline RHE & $7.7 \pm 0.5^{\mathrm{b}}$ & $8.7 \pm 0.6^{\mathrm{a}}$ & $7.5 \pm 0.5^{b}$ & $7.6 \pm 0.5^{b}$ \\
\hline $\mathrm{PCO}$ & $7.9 \pm 0.5^{\mathrm{b}}$ & $8.8 \pm 0.6^{\mathrm{a}}$ & $7.8 \pm 0.6^{\mathrm{b}}$ & $7.9 \pm 0.5^{\mathrm{b}}$ \\
\hline Water & $7.6 \pm 0.6^{\mathrm{b}}$ & $8.4 \pm 0.9^{\mathrm{a}}$ & $7.9 \pm 0.8^{\mathrm{b}}$ & $7.7 \pm 0.6^{\mathrm{b}}$ \\
\hline \multicolumn{5}{|c|}{ Packed Cell Volume (\%) } \\
\hline RHE & $33.7 \pm 3.7^{b}$ & $49.2 \pm 1.0^{\mathrm{a}}$ & $34.0 \pm 3.1^{\mathrm{b}}$ & $32.9 \pm 3.1^{\mathrm{b}}$ \\
\hline $\mathrm{PCO}$ & $32.7 \pm 4.5^{\mathrm{b}}$ & $48.9 \pm 5.8^{\mathrm{a}}$ & $33.0 \pm 3.6^{\mathrm{b}}$ & $32.5 \pm 3.8^{\mathrm{b}}$ \\
\hline Water & $32.9 \pm 4.0^{\mathrm{b}}$ & $46.1 \pm 4.7^{\mathrm{a}}$ & $33.1 \pm 4.0^{\mathrm{b}}$ & $32.7 \pm 3.2^{\mathrm{b}}$ \\
\hline \multicolumn{5}{|c|}{ Creatinine $\left(\mathrm{mg} \mathrm{dL}^{-1}\right) *$} \\
\hline RHE & $1.1 \pm 0.2^{b}$ & $1.4 \pm 0.3^{\mathrm{a}}$ & $1.2 \pm 0.1^{b}$ & $1.2 \pm 0.2^{b}$ \\
\hline $\mathrm{PCO}$ & $1.1 \pm 0.2^{\mathrm{b}}$ & $1.4 \pm 0.2^{\mathrm{a}}$ & $1.1 \pm 0.2^{\mathrm{b}}$ & $1.2 \pm 0.2^{\mathrm{b}}$ \\
\hline Water & $1.1 \pm 0.1^{\mathrm{b}}$ & $1.3 \pm 0.2^{\mathrm{a}}$ & $1.2 \pm 0.1^{\mathrm{b}}$ & $1.2 \pm 0.1^{\mathrm{b}}$ \\
\hline \multicolumn{5}{|c|}{ Glucose $\left(\mathrm{mg} \mathrm{dL}^{-1}\right)^{*}$} \\
\hline RHE & $89.5 \pm 9.2^{b}$ & $114.0 \pm 17.5^{\mathrm{a}}$ & $98.7 \pm 13.4^{\mathrm{b}}$ & $84.2 \pm 8.3^{b}$ \\
\hline $\mathrm{PCO}$ & $94.9 \pm 12.7^{\mathrm{b}}$ & $111.5 \pm 16.6^{\mathrm{a}}$ & $90.5 \pm 7.0^{\mathrm{b}}$ & $88.9 \pm 4.5^{b}$ \\
\hline Water & $87.0 \pm 7.9^{\mathrm{b}}$ & $113.0 \pm 17.4^{\mathrm{a}}$ & $87.9 \pm 6.4^{b}$ & $87.5 \pm 5.6^{\mathrm{b}}$ \\
\hline \multicolumn{5}{|c|}{ Lactate $\left(\mathrm{mg} \mathrm{dL}^{-1}\right) *$} \\
\hline RHE & $5.4 \pm 2.3^{b}$ & $106.1 \pm 55.6^{\mathrm{a}}$ & $4.4 \pm 1.4^{b}$ & $4.5 \pm 2.8^{b}$ \\
\hline $\mathrm{PCO}$ & $4.8 \pm 2.1^{\mathrm{b}}$ & $105.4 \pm 59.9^{\mathrm{a}}$ & $4.2 \pm 1.6^{\mathrm{b}}$ & $4.6 \pm 2.5^{b}$ \\
\hline Water & $4.8 \pm 1.9^{b}$ & $100.9 \pm 40.2^{\mathrm{a}}$ & $5.3 \pm 2.0^{\mathrm{b}}$ & $4.4 \pm 1.1^{\mathrm{b}}$ \\
\hline
\end{tabular}

Mean values followed by different lower case letters on the same line or by upper case letters in the same column are different $(\mathrm{p}<0.05)$ according to the Tukey test or * Dunkan test.

There was no difference in plasma glucose between treatment groups $(\mathrm{P}>0.05)$, but there was a difference $(\mathrm{P}<0.05)$ in its concentration throughout the experimental phase (Table 2). At T1, a higher concentration of this carbohydrate $(\mathrm{P}<0.05)$ was observed in the animals of the three treatment groups. However, the values recorded at T1 were not higher than the reference values determined by Kaneko et al. (2008).

In the present study, the increase in the plasma concentration of glucose at $\mathrm{T} 1$ indicates that the mobilization of glucose exceeded the capacity for metabolization by the muscles (BALARIN et al., 2005). This is due to the ability of exercise to stimulate hepatic glycogenolysis (HODGSON et al., 1994) to meet tissue energy demand. The RHE group at T3 had a higher concentration of glucose than the other groups during the treatment phase, although the difference was not significant. This higher glycemic rate may be related to the higher ingested volume of the solution by the animals of that group $(18.2 \mathrm{~L})$ compared to the other groups. These results agree with those obtained by Donner (2013), who observed elevated glycemia in animals that ingested a hydroelectrolytic repository.

There was no difference in the plasma glucose concentration between the PCO and control groups $(\mathrm{P}>0.05)$ throughout the treatment phase (T3 and T6). In the PCO group, this result was associated with the low concentration of this carbohydrate in the commercial product's composition; in the animals in the control group, it was due to the absence of carbohydrates. The use of electrolytic solutions with an energetic substrate is essential, both in dehydrated, diseased animals and in animals that have lost fluid and electrolytes after exercise 
(RIBEIRO FILHO et al., 2014a), and is fundamental for restoring muscle glycogen and maintaining the animal's energy balance (WALLER et al., 2007).

The plasma lactate concentration did not show any difference between treatments $(\mathrm{P}>0.05)$. At $\mathrm{T} 1$, there was an increase $(\mathrm{P}<0.05)$ in lactate concentration in the animals in all treatment groups, exceeding the reference values cited by Radostits et al. (2006) and Kaneko et al. (2008). These results were similar to those obtained by Farias (2009), Ferraz et al. (2010), Zobba et al. (2011), and Donner (2013). According to Farias (2009), the increase in plasma lactate after exercise is due to the use of the anaerobic metabolic pathway to obtain energy, as lactate is produced in large quantities in the muscles.

From T3, there was a reduction in lactate concentration to values similar to $\mathrm{T} 0$ in the animals of all treatments, remaining constant at T6. High lactate values in the rehydration phase were recorded by Donner (2013); the study reported that the high maintenance of plasma lactate was a consequence of fermentation of the carbohydrates present in the rehydration solution by the animals' intestinal microbiota. The absence of this finding in the animals treated with RHE expresses a positive fact about the solution tested in this study. That is, the amount of carbohydrates did not generate excessive fermentation, which is always desirable.

There were no differences $(\mathrm{P}>0.05)$ in serum sodium concentrations between treatments, or in treatments over time (Table 3). Depending on the duration and intensity of physical activity, changes in electrolyte concentrations in blood may occur. Fernandes and Larsson (2000) and Farias (2009) observed a reduction in the concentration of this ion after exercise, and Farias stated that the observed reduction occurred due to loss through sweating during physical activity. Souza et al. (2009) and Donner (2013) reported no change in the concentration of this electrolyte. As there was no significant decrease in serum sodium after exercise, both treatments (RHE and PCO), although containing sodium, were not able to express their effect, as the kidneys usually maintain the blood concentration by excreting or absorbing sodium via urine, emphasizing that this mechanism occurs when the electrolytic imbalances are not accentuated and when the kidneys are not affected by diseases. In this way, it can be said that in addition to measuring serum and plasma electrolyte levels, urine should also be checked. Unfortunately, the measurement of urine electrolytes was not performed on the animals in the present trial.

Serum concentrations of potassium were different $(\mathrm{P}<0.05)$ only among the treatments, and there was no difference in the treatments during the experimental phase (Table 3). The animals treated with RHE presented a lower concentration of this electrolyte when compared to the other groups. However, it was observed that the values obtained were similar from $\mathrm{T} 0$ to $\mathrm{T} 6$. That is, the lower serum potassium value of the RHE treatment in relation to PCO and the control was maintained throughout the experimental phase. Thus, the difference cannot be attributed to the exercise nor to the treatment, as the values remained constant from $\mathrm{T} 0$ to $\mathrm{T} 6$. Moreover, they remained within the reference range determined by Kaneko et al. (2008).

In horses that participated in polo matches, as in the present study, no change was detected in the serum potassium concentration after the match (FERRAZ et al., 2010; ARAÚJO, 2013), though the decrease in serum concentration of this electrolyte in horses after physical activity was recorded by Craig et al. (1985), Fernandes and Larsson (2000), Farias (2009), and Donner (2013). Although there was no decrease in serum or plasma potassium after exercise, it is important to offer potassium-containing repositories because, according to Flaminio and Rush (1998), there is a return of potassium to the inside of the cells after exercise, which causes a significant reduction in the serum concentration of this ion and may lead to hypokalemia. 
Table 3. Mean and standard deviation of the serum concentration of sodium, potassium, calcium, magnesium, phosphorus, and chloride in horses before exercise (T0), immediately after exercise (T1), and after 3 (T2) and 6 (T3) hours after exercise.

\begin{tabular}{|c|c|c|c|c|}
\hline \multirow{2}{*}{ Groups } & \multicolumn{4}{|c|}{ Time evaluation } \\
\hline & T0 & $\mathrm{T} 1$ & $\mathrm{~T} 2$ & $\mathrm{~T} 3$ \\
\hline \multicolumn{5}{|c|}{ Sodium $\left(\mathrm{mEq} \mathrm{L}^{-1}\right)$} \\
\hline RHE & $128.7 \pm 5.5$ & $132.7 \pm 9.0$ & $130.5 \pm 6.8$ & $132.5 \pm 7.9$ \\
\hline $\mathrm{PCO}$ & $135.6 \pm 5.8$ & $139.1 \pm 9.1$ & $132.5 \pm 8.1$ & $133.0 \pm 5.9$ \\
\hline Water & $135.0 \pm 5.2$ & $133.8 \pm 4.0$ & $129.6 \pm 6.9$ & $130.9 \pm 7.0$ \\
\hline \multicolumn{5}{|c|}{ Potassium $\left(\mathrm{mEq} \mathrm{L}^{-1}\right) *$} \\
\hline RHE & $3.4 \pm 0.2^{\mathrm{B}}$ & $3.3 \pm 0.3^{\mathrm{B}}$ & $3.4 \pm 0.3^{\mathrm{B}}$ & $3.6 \pm 0.4^{\mathrm{B}}$ \\
\hline $\mathrm{PCO}$ & $3.8 \pm 0.4^{\mathrm{A}}$ & $3.7 \pm 0.4^{\mathrm{A}}$ & $3.8 \pm 0.5^{\mathrm{A}}$ & $3.8 \pm 0.4^{\mathrm{A}}$ \\
\hline Water & $3.9 \pm 0.2^{\mathrm{A}}$ & $3.7 \pm 0.4^{\mathrm{A}}$ & $3.6 \pm 0.3^{\mathrm{A}}$ & $3.6 \pm 0.4^{\mathrm{A}}$ \\
\hline \multicolumn{5}{|c|}{ Calcium (mg dL $\left.{ }^{-1}\right)$} \\
\hline RHE & $13.17 \pm 1.27$ & $12.93 \pm 1.17$ & $13.35 \pm 0.71$ & $13.43 \pm 1.27$ \\
\hline $\mathrm{PCO}$ & $11.11 \pm 0.94$ & $12.33 \pm 0.73$ & $12.66 \pm 0.93$ & $12.91 \pm 0.93$ \\
\hline Water & $13.61 \pm 0.53$ & $13.50 \pm 0.74$ & $13.64 \pm 1.04$ & $13.45 \pm 0.72$ \\
\hline \multicolumn{5}{|c|}{ Magnesium $\left(\mathrm{mg} \mathrm{dL}^{-1}\right)$} \\
\hline RHE & $4.9 \pm 0.3$ & $4.9 \pm 0.3$ & $4.7 \pm 0.3$ & $5.0 \pm 0.6$ \\
\hline $\mathrm{PCO}$ & $4.8 \pm 0.3$ & $4.8 \pm 0.2$ & $4.6 \pm 0.2$ & $4.6 \pm 0.2$ \\
\hline Water & $4.7 \pm 0.3$ & $4.9 \pm 0.3$ & $4.8 \pm 0.3$ & $4.6 \pm 0.2$ \\
\hline \multicolumn{5}{|c|}{ Phosphorus $\left(\mathrm{mg} \mathrm{dL}^{-1}\right) *$} \\
\hline RHE & $4.0 \pm 1.4^{\mathrm{Ab}}$ & $5.0 \pm 1.4^{\mathrm{Aa}}$ & $3.6 \pm 0.5^{\mathrm{Bb}}$ & $3.8 \pm 0.7^{\mathrm{Bb}}$ \\
\hline $\mathrm{PCO}$ & $4.9 \pm 0.9^{\mathrm{Ab}}$ & $5.7 \pm 0.8^{\mathrm{Aa}}$ & $4.4 \pm 0.6^{\mathrm{Ab}}$ & $4.9 \pm 0.5^{\mathrm{Ab}}$ \\
\hline Water & $4.2 \pm 0.9^{\mathrm{Ab}}$ & $5.0 \pm 0.9^{\mathrm{Aa}}$ & $4.5 \pm 0.9^{\mathrm{Ab}}$ & $4.7 \pm 0.8^{\mathrm{Ab}}$ \\
\hline \multicolumn{5}{|c|}{ Chloride $\left(\mathrm{mEq} \mathrm{L}^{-1}\right) *$} \\
\hline RHE & $101.0 \pm 1.3^{\mathrm{a}}$ & $98.8 \pm 2.0^{b}$ & $100.7 \pm 1.5^{\mathrm{ab}}$ & $100.2 \pm 2.5^{b}$ \\
\hline $\mathrm{PCO}$ & $100.5 \pm 1.5^{\mathrm{a}}$ & $98.5 \pm 1.8^{\mathrm{b}}$ & $99.3 \pm 1.7^{\mathrm{ab}}$ & $98.8 \pm 1.4^{\mathrm{b}}$ \\
\hline Water & $101.1 \pm 2.5^{\mathrm{a}}$ & $99.1 \pm 2.6^{b}$ & $99.9 \pm 2.9^{\mathrm{ab}}$ & $99.9 \pm 2.8^{b}$ \\
\hline
\end{tabular}

Mean values followed by different lower case letters on the same line or by upper case letters in the same column are different $(\mathrm{p}<0.05)$ according to the Tukey test or * Dunkan test.

Serum calcium and total magnesium concentrations did not differ $(\mathrm{P}>0.05)$ between treatments or times (Table 3). In the present study, the difference between the RHE group and the other groups was expected, since the hydroelectrolytic repositories contained magnesium pidolate. Therefore, in the present study, the duration of the polo match was not sufficient to cause changes in serum magnesium concentration, nor was the amount present in the hydroelectrolytic repository sufficient to generate an increase in the total serum calcium and magnesium values.

There was a difference $(\mathrm{P}<0.05)$ in the serum concentration of phosphorus between treatments and between times (Table 3). In all treatments, there was an increase $(\mathrm{P}<0.05)$ in the concentration of phosphorus at T1. According to Rose et al. (1983), the increase in phosphorus concentrations after exercise occurs due to dephosphorylation of ATP for energy production during muscular work. At T3 and T6, the animals treated with RHE presented inferior values of phosphorus when compared to animals receiving $\mathrm{PCO}$ or water. As the RHE contained glucose, the cause of this event was due to the ability of this carbohydrate to induce insulin secretion and promote the influx of phosphorus and other electrolytes into cells, as mentioned in Kaneko et al. (2008). In turn, the reduction of the phosphorus concentration in the PCO and water groups in T3 and T6 was expected, as this electrolyte was not part of its composition. 
There was no significant difference in chloride concentration between treatments, only between times $(\mathrm{P}<0.05)$. The reduction observed at $\mathrm{T} 1$ can be explained by the loss of this element by sweating, since the sweat of these animals contains up to twice as much chloride as the plasma (FLAMINIO; RUSH, 1998). Lacerda-Neto et al. (2003) stated that there is a relationship between chloride loss and exercise intensity. Thus, prolonged or intense sweating may cause a reduction of this electrolyte during and after physical activity, generating greater retention of bicarbonate by the kidneys and triggering the appearance of metabolic alkalosis. During the rehydration phase of the animals (T3 and T6), the serum concentration of this electrolyte remained constant and within the range determined by Kaneko et al. (2008). A more significant increase was expected in animals in the RHE and PCO groups as both treatments contained chloride, but, possibly due to the same mechanism described for serum sodium values, this did not occur.

\section{Conclusions}

It was concluded that the ingested volume of the hydroelectrolytic repositories by the animals was higher than the commercial paste and control groups. In addition, the intake did not change the animals' biochemical or electrolytic profiles, emphasizing that additional studies evaluating horses submitted to other athletic modalities are necessary.

\section{Special Thanks}

To the Military Academy of the Agulhas Negras (AMAN) for allowing the study to be conducted using its animals and facilities.

\section{References}

ARAÚJO, P. C. Demandas fisiológicas e alterações decorrentes do esforço em equinos de polo de baixo handicap. 2013. Dissertação (Mestrado em Saúde Animal) - Faculdade de Agronomia e Medicina Veterinária, Universidade de Brasília, Brasília.
ASSENZA, A.; BERGERO, D.; CONGIU, F.; TOSTO, F.; GIANNETTO, C.; PICCIONE, G. Evaluation of serum electrolytes and blood lactate concentration during repeated maximal exercise in horse. Journal of Equine Veterinary Science, Philadelphia, v. 34, n. 10, p. 11751180, 2014.

BALARIN, M. R. S.; LOPES, R. S.; KOHAYAGAWA,A.; LAPOSY, C. B.; FONTEQUE, J. H. Avaliação da glicemia e da atividade sérica de aspartato aminotransferase, creatinoquinase, gama - glutamiltransferase e lactato desidrogenase em equinos Puro Sangue Inglês (PSI) submetidos a exercícios de diferentes intensidades. Semina: Ciências Agrárias, Londrina, v. 26, n. 2, p. 211218, 2005.

COENEN, M. Exercise and stress: impact on adaptive processes involving water and electrolytes. Livestock Production Science, Philadelphia, v. 92, n. 2, p. 131-145, 2005.

CRAIG, L.; HINTZ, H. F.; SODERHOLM, L. V.; SHAW, K. L.; SCHRYVER, H. F. Changes in blood constituents accompanying exercise in polo horses. The Cornell Veterinarian, New York, v. 75, n. 2, p. 297-302, 1985.

CROCOMO, L. F.; BALARIN, M. R.; TAKAHIRA, R. K.; LOPES, R. S. Macrominerais séricos em equinos atletas da raça Puro Sangue Inglês, antes e após exercício físico de alta intensidade. Revista Brasileira de Saúde e Produção Animal, Salvador, v. 10, n. 4, p. 929-938, 2009.

DONNER, A. C. Efeito da ingestão ad libitum de repositor hidroeletrolitico e energético em equinos submetidos ao treinamento de marcha. 2013. Dissertação (Mestrado em Medicina Veterinária) - Curso de Pós-Graduação em Medicina Veterinária. Universidade Federal de Viçosa, Viçosa, MG.

DUSTERDIECK, K. F.; SCHOTT II, H. C.; EBERHART, S. W.; WOODY, K. A.; COENEN, M. Electrolyte and glycerol supplementation improve water intake by horses performing a simulated $60 \mathrm{~km}$ endurance ride. Equine Exercise Physiology, Cambridge, v. 30, n. 30, p. 418-424, 1999.

FARIAS, S. K. Efeito do exercício sobre parâmetros clínicos, hematológicos e bioquímicos em equinos Mangalarga Marchador. 2009. Monografia (Trabalho de Conclusão de Curso de Especialização em Clínica e Cirurgia de Grandes Animais) - Curso de Pós-Graduação em Medicina Veterinária. Universidade Federal de Viçosa, Viçosa.

FERNANDES, W. R.; LARSSON, M. H. Alterações nas concentrações séricas de glicose, sódio, potássio, ureia e creatinina, em equinos submetidos a provas de enduro de $30 \mathrm{~km}$ com velocidade controlada. Ciência Rural, Santa Maria, v. 30, n. 3, p. 393-398, 2000. 
FERRAZ, G. C.; SOARES, O. A.; FOZ, N. S.; PEREIRA, M. C.; QUEIROZ-NETO, A. The workload and plasma ion concentration in a training match session of high-goal (elite) polo ponies. Equine Veterinary Journal, Medford, v. 42, n. 38, p. 191-195, 2010.

FLAMINIO, M. J.; RUSH, B. R. Fluid and electrolyte balance in endurance horses. Veterinary Clinics of North America: Equine Pratice, Maryland Heights, v. 14, n. 1, p. 147-158, 1998.

GOMES, A. T. Balanço eletrolítico em cavalos de enduro: alterações, suplementação e reposição de eletrólitos. 2014. Monografia (Trabalho de Conclusão de Curso de Graduação em Medicina Veterinária) - Faculdade de Veterinária, Universidade Federal do Rio Grande do Sul, Porto Alegre.

GONDIN, M. R.; FOZ, N. S.; PEREIRA, M. C.; FLAGLIARI, J. J.; OROZCO, C. A.; D’ANGELI, F. H.; HODGSON, D. R.; DAVIS, R. E.; McCONAGHY, F. F. Acute phase responses of different positions of high-goal (elite) polo ponies. Journal of Equine Veterinary Science, Philadelphia, v. 33, n. 11, p. 956-961, 2013.

HODGSON, D. R.; MCKEEVER, K. H.; MCGOWAN, C. M. Thermoregulation in the horse in response to exercise. British Veterinary Journal, London, v. 150, n. 3, p. 219-235, 1994.

HOLBROOK, T. C.; SIMMONS, R. D.; PAYTON, M. E.; MACALLISTER, C. G. Effect of repeated oral administration of hypertonic electrolyte solution on equine gastric mucosa. Equine Veterinary Journal, Medford, v. 37, n. 6, p. 501-504, 2005.

HYYPPÄ, S. Endocrinal responses in exercising horses. Livestock Production Science, Amsterdam, v. 92, n. 2, p. 113-121, 2005.

HYYPPÄ, S.; SAASTAMOINEN, M.; PÖSÖ, A. R. Restoration of water and electrolyte balance in horses after repeated exercise in hot and humid conditions. Equine Veterinary Journal, Medford, v. 28, n. 22, p. 108112, 1996.

KANEKO, J. J.; HARVEY, J. W.; BRUSS, M. L. Clinical biochemistry of domestic animals. $6^{\text {th }}$ ed. Burlington: Elsevier, 2008. 916 p.

LACERDA-NETO, J. C.; SAMPAIO, R. D.; FERRAZ, G. C.; TEIXEIRA-NETO, A. R.; PEREIRA, D. M.; TITTO, E. A.; CARVALHO, M. B.; QUEIROZ-NETO, A. D. Efeitos do resfriamento intermitente e de repositor eletrolítico sobre a osmolalidade e eletrólitos séricos de equinos submetidos a exercício de baixa intensidade. Revista Portuguesa de Ciências Veterinárias, Lisboa, v. 98, n. 548, p. 189-195, 2003.
LINDINGER, M. I.; ECKER, G. L. Gastric emptying, intestinal absorption of electrolytes and exercise performance in electrolyte-supplemented horses. Experimental Physiology, London, v. 98, n. 1, p. 193206, 2013.

MARLIN, D.; SCOTT, C. M.; MILLS, P. C.; LOUWES, H.; VAARTEN, J. Rehydration following exercise: effects of administration of water versus an isotonic Oral Rehydration Solution (ORS). The Veterinary Journal, London, v. 156, n. 1, p. 41-49, 1998.

MCCUTCHEON, L. J.; GEOR, R. J.; ECKER, G. L.; LINDINGER, M. I. Equine sweating responses to submaximal exercise. Journal of Applied Physiology, Rockville Pike, v. 87, n. 3, p. 1843-1851, 1999.

PUOLI FILHO, J. N.; BARROS NETO, T. L.; RODRIGUES, P. H.; GARCIA, H. P. Parâmetros fisiológicos do desempenho de cavalos de alta performance hidratados voluntariamente com água ou solução isotônica contendo carboidrato. Brazilian Journal of Veterinary Research and Animal Science, São Paulo, v. 44, n. 2, p. 122-131, 2007.

RADOSTITS, O. M.; GAY, C. C.; HINCHCLIFF, K. W.; CONSTABLE, P. D. Veterinary medicine: atextbook of the diseases of cattle, horses, sheep, pigs and goats. $10^{\text {th }}$ ed. Philadelphia: Saunders, 2006. 2162 p.

RIBEIRO FILHO, J. D.; FARIAS, S. K.; DONNER, A. C.; OLIVEIRA, D. P.; GUIMARÃES, J. D.; SOUZA, M. V.; GOMES, C. L. N.; AVANZA, M. F. B. Efeito de soluções eletrolíticas enterais com diferentes osmolaridades sobre o perfil eletrolítico e bioquímico de equinos. Pesquisa Veterinária Brasileira, Seropédica, v. 34, n. 2, p. 179-184, 2014a.

RIBEIRO FILHO, J. D.; PESSIN, A. E.; ATOJI, K.; SOUZA, M. V.; GOMES, C. L.; SILVA, A. R. Enteral fluid therapy: biochemical profile of horses treated with hypotonic enteral electrolyte solutions associated with energy sources. Journal of Equine Veterinary Science, Philadelphia, v. 34, n. 6, p. 759-764, 2014 b.

ROSE, R. J.; ALLEN, J. R.; HODGSON, D. R.; STEWART, J. H.; CHAN, W. Responses to submaximal treadmill exercise and training in the horses: change in haematology, arterial blood gas and acid base measurements, plasma biochemical values and heart rate. The Veterinary Record, London, v. 113, n. 26-27, p. 612618, 1983.

SISTEMA DE ANÁLISES ESTATÍSTICAS E GENÉTICAS - SAEG - Versão 9.1. Viçosa, MG: Fundação Arthur Bernardes, UFV, 2007. 
SAMPIERI, F.; SCHOTT II, H. C.; HINCHCLIFF, K. W.; GEOR, R. J.; JOSE-CUNILLERASS, E. Effects of oral electrolyte supplementation on endurance horses competing in $80 \mathrm{~km}$ rides. Equine Veterinary Journal, Medford, v. 38, n. 36, p. 19-26, 2006.

SANTOS, V. P. Variações hemato-bioquímicas em equinos de salto submetidos a diferentes protocolos de exercício físico. 2006. Dissertação (Mestrado em Ciências Veterinárias) - Faculdade de Medicina Veterinária. Universidade Federal do Rio Grande do Sul, Porto Alegre.

SHIRREFFS, S. M.; ARAGON-VARGAS, L. F.; CHAMORRO, M.; MAUGHAN, R. J.; SERRATOSA, L.; ZACHWIEJA, J. J. The sweating response of elite professional soccer players to training in the heat. International Journal of Sports Medicine, New York, v. 22, n. 2, p. 90-95, 2005.

SICILIANO, P. D.; LAWRENCE, L. M.; DANIELSE, K.; POWELL, D. M.; THOMPSON, K. N. Effect of conditioning and exercise type on serum creatinekinase and aspartate aminotransferase activity. Equine Veterinary Journal, Medford, v. 27, n. 18, p. 243-241, 1995.

SOSA LEÓN, L. A.; HODGSON, D. R.; CARLSON, G. P.; ROSE, R. J. Effects of concentrated electrolytes administered via a paste on fluid, electrolyte, and acid base balance in horses. American Journal of Veterinary Research, Chicago, v. 59, n. 7, p. 898-903, 1998.
SOUZA, B. G.; HESS, T. M.; ALMEIDA, F. Q.; MELLO, E. B. F. R. B.; OLIVEIRA, G. F.; CHAVES, J. P.; VEGGA, C. C. P. Effects of potassium free and potassium rich electrolytes on dietary cation-anion balance and on plasma electrolytes and acid-base balance in eventing horses. Journal of Equine Veterinary Science, Philadelphia, v. 29, n. 5, p. 366- 367, 2009.

TEIXEIRA-NETO, A. R.; FERRAZ, G. D.; MATAQUEIRO, M. I. Reposição eletrolítica sobre variáveis fisiológicas de cavalos em provas de enduro de 30 e 60 km. Ciência Rural, Santa Maria, v. 34, n. 5, p. 1505-1511, 2004.

WALLER, A.; HEIGENHAUSER, G. J.; LINDINGER, M. I. Electrolyte supplementation after prolonged moderate-intensity exercise results in decreased plasma [TCO2] in Standardbreds. Equine and Comparative Exercise Physiology, Cambridge, v.4, n. 3, p. 149-158, 2007.

ZOBBA, R.; ARDU, M.; NICCOLINI, S.; CUBEDDU, F.; DIMAURO, C.; BONELLI, P.; DEDOLA, C.; VISCO, S.; PARPAGLIA, M. P. Physical, hematological, and biochemical responses to acute intense exercise in polo horses. Journal of Equine Veterinary Science, Philadelphia, v. 31, n. 8, p. 542-548, 2011. 
